\title{
Counselling the Stigmatized: A Panacea for Rejecting Self-Degradation While Promoting Self-Attainment
}

\author{
Barr. (Mrs) Mary L. Effiong Ph.D \\ Directorate Of Counselling And Human Development \\ Obong University \\ Obong-Ntak \\ Akwa Ibom State \\ Prof. Danieli. Denga \\ Faculty Of Education \\ Benue State University \\ Makurdi
}

\begin{abstract}
This study investigated selected variables such as socioeconomic status and self-concept which have apparently influenced the stigmatized who require counselling as a panacea for rejecting self-degradation but promoting selfattainment in Akwa Ibom State.The researcher adopted an ex-post factor design to elicit responses from a sample of 1500 (25\%) of a population of 6010 civil servants in Akwa Ibom State. A purposive sample was affected since the stigmatized were obviously identified. Two null hypotheses were postulated and tested after the research. Questions were asked about the extent to which stigmatization has degraded civil servants.It was found out that: Self-concept significantly influenced the self-attainment of the stigmatized. Socio economic status significantly influenced the selfattainment of the stigmatized.
\end{abstract}

\section{Introduction}

Stigma or stigmata which is a Greek word was used as a mark on those known as criminals, slaves or traitors for easier identification. These individuals were to be avoided or shunned particularly in public. The word stigmatization which was later extended to other personal attributes that are considered discrediting or shameful are grouped by social psychologist into three classes which are tribal stigma, weakness or defect of individual characters as well as physical deformities. The stigma can be as a result of subtle conditions.

The process of stigmatization involves labeling differences as undesirable and often results in social exclusion, disempowerment, discrimination so as to be justified to be forced out or isolated. Goffman, (2010) identified the internal consequences for the stigmatized individual as self-devaluated, being rejected or marginalized. Many such stigmatized persons then internalized the social meaning of that label.

It suffices to mention, other types of stigma which are structural stigma which has to do with particularly policies of large entities like institutions, government that place certain rights/ restrictions on certain group of people. Then selfstigma which is labelled by the person concerned example Adam and Eve in the garden of Eden. (Gen. 3:9-10)

Although knowledge of self-stigmatization being a social process that imputes definition to human experience is of worth to a stigmatized, the nature, intensity and subjectiveness of self-stigma vary in relation to gender, age, culture, sexual orientation, socioeconomic status and other important aspect of identity.

From research findings, be it biological, structural and or self-stigmatized, the negative effect a stigma can impact on an individual livelihood as their consequences include diminished self-esteem, self-efficacy and confidence in ones' future (Carringan, 2010).

Though some stigmatized could be as a result of danger, uncertainty, incompetence, irresponsiveness or even unpredictability, most often than none, stigma maybe caused by ignorance. Little wonder in the days of Jesus Christ, stigmatized were on different grounds like the woman with the issue of blood- Matt. 9:20, tax collector- Lk. 18:9-14, rich man and poor man- Lk. 16:19-31, prostitution Practice-Lk. 7:36-50.Irrespective of the type, kind and nature of the stigmatized, the menace is nothing to joke over as its negative effects are multi-factional. The findings of Coff, (2011) confirms this by stating that stigmatized have difficulties in finding housing as well as jobs and were frequently harassed on the streets and at the same time socially isolated. This is nothing but an evidence of the stigmatized not affecting him/herself only but the entire human race as it affects the Gross Domestic Product (GDP) of such country. 


\subsection{Research Questions}

2.1 To what extent can counselling influence self-attainment of a stigmatized?

2.2 How can self-concept influence self-attainment of a stigmatized?

2.3 How can socioeconomic status influence self-attainment of the stigmatized?

\subsection{Statement of Hypotheses}

3.1 Self-concept cannot significantly influence the self- attainment of the stigmatized.

3.2 Socioeconomic status cannot significantly influence the self-attainment of the stigmatized.

\subsection{Counselling:}

The term counselling is of American origin coined by Rogers in U.S as a result of world war II because of the military need for vacation placement and training which made the veterans administrator create a specialty called counselling. From then, counselling profession expanded to many countries around the world.

According to Hills, (2014) counselling psychologist are employed into a variety of settings depending on the services they provide and client population they serve.

Whiston \& Rahardja (2008), counseling is a mental health service that multitude of people throughout the world need. Because life is stressful and difficult but by awareness through counselling, it becomes bearable. In fact, one of the most reliable and consistent ways to get help navigating some of life challenges is by seeking counseling for this section shall permit deeper expression that the client would ordinarily allow her/himself not minding some barriers associated with counselling; Gelso, Williams \& Fretz (2014) stated that 2004 study of Americans asserted that $48 \%$ of Americans were actively seeking out mental health treatment. This goes to ascertain the worth of counselling by recognizing a sudden positive shift in their lives and improve emotional wellbeing.

Counselling is an excellent way to treat any depressive condition, even suicidal ideation including mental illness. This is so because at counselling one feels save to express any feeling a person would have felt difficulty to express. Perhaps this is so because a counsellor is dedicated to helping people get a place of emotional wellness and stability. Hence, counselling supports a stigmatized in their journey to wellness in spite of what so ever kind of depression, socioeconomic status and self-concept.

\subsection{Self-concept}

Self-concept which is how one sees and understands his/her self is not a happenstance issues because its occurrence is generic in nature. Self-concept apart from family beliefs and practices, emanate from sub-variables like moral as well as social concept. As a matter of fact, moral that has to do with self-control, compliance and self-esteem is an issue that cannot be over emphasized when it comes to self-attainment, little wonder Oliner \& Oliner (1988) found that rescuers with good parental values were properly involved and sustained after the world war II.

This finding was corroborated by Park and Waters (2009) when they confirmed that children with secure attachment comparatively had more harmonious interaction with peers. Similarly, Ormrod (2006) had earlier asserted that social self-concept is the acquisition of skills that developed exclusively or primarily within a social group which can affect positively or negatively self-efficacy which is the extent or strength of a person's beliefs in his/her ability to complete tasks and reach set goals for self-attainment. Therefore, social self-concept of a person should be treated or considered important and vital to self-attainment though family self-concept remains paramount.

\subsection{Socio-economic Status}

Socioeconomic status (SES) is an economic and sociological combined total measure of a persons' work experience and relation to other including education attainment. Socioeconomic status which is typically broken into three levels high, middle and low is more often than none used to express an economic difference in society.

Development and education attainment according to Effiong, (2016) are determinant factors amongst others to socioeconomic status because without prejudice, the higher the development and education attainment of a person, the higher his or her income which of course is one of the features of socioeconomic status. This goes to support Leigh, (2009) who argued that families with lower income do not participate in what he termed concerted cultivation whereby parents take an active role in their children's education and development through controlled organized activities thereby causing the children sense of constraint.

As a matter of research, socioeconomic status is no longer a phenomenon of tripod dimension - income, development and education, but rest on other prodigies known as behaviors, characters and conducts. 


\subsection{Research Design:}

The ex-post facto design was adopted for this research because the researcher was not able to manipulate the independent variables which are counselling, self-concept and socioeconomic status therefore they have no real control over any possible causes.

\subsection{Area of the Study:}

The area of the study which is Akwa Ibom State is Named after Qua Ibo River.

\subsection{Population of the Study:}

The target population for this study is six thousand and ten $(6,010)$ civil servants working in Akwa Ibom State Ministries, agencies, boards, bureaus, commissions and parastatals retrieved from payroll and statistic department of each ministry.

\subsection{Sampling Technique:}

The researcher used purposive sampling technique to choose five departments which were account, administration, audit, registry and payroll because there were found in all the 20 ministries.

\subsection{Sample:}

A sum of one thousand, five hundred $(1,500)$ sample size was selected using stratified random sampling technique.

\subsection{Instrumentation:}

Counselling the stigmatized Questionnaire (COSQU) was constructed and developed for male and female civil servants working presently in 20 ministries in Akwa Ibom State Civil Service. The instrument Counselling the Stigmatized Questionnaire which is made up of three sections A,B and C with 27 items was constructed for use to test the formulated hypothesis.

\subsection{Validity of the Instrument:}

The entire Counselling the Stigmatized Questionnaire was given to experts to confirm the first validity then to experts in counselling, measurement and evaluation for general vetting which reduced the items to 27-7, 10 and 10 respectively.

\subsection{Reliability of the Instrument:}

Before conducting pilot testing on fifty (50) civil servants who were exempted from the main exercise, the researcher used Factor Analysis or Cronbach Alpha (a) to cut down the numbers of items on each variable for only the relevant ones to prevail.

\subsection{Procedure for Data Collection:}

The research instrument that was developed out from the sub-theme was administered on the purposively selected male and female civil servants working in Akwa Ibom State Ministries

\subsection{Procedure for Data Preparation \& Scoring:}

The modified 4-point likert scale was used as a base of scoring scale. While all the positive items were scored 4,3,2 and 1 , the negative items were scored in reverse 4,3,2 and 1 respectively.

\subsection{Procedure of Data Analysis}

The three (3) research questions alongside with the two (2) hypothesis that are used in this study are stated in the null form and the appropriate statistics analysis were applied using frequency and percentage then independent t-test at .05 level of significance during testing. Hypothesis 1:Self-concept of stigmatized in Akwa Ibom State does not significantly influence the self-attainment.

\subsection{Findings}

Going through the results of the findings conducted to establish the extent 113ounseling services on the stigmatized influence their self-attainment, it is observed that there had been a lot of disagreement among civil servants over all the sub-variables used. This result goes to confirm evangelistic and Huston (1994) in Okokon (2011) when they postulated that when stigmatized begin to decline in their level of awareness and satisfaction, there is bound to be depression which can hinder self-attainment. This result shows that the presence of positive self-concept can influence the selfattainment of the stigmatized. This supports Udoh (2014) who says that self-concept is a necessity to better selfattainment. The place of socioeconomic status is another crucial issue in the self-attainment of the stigmatized. Olanyinka (2013) threw more light on this assertion when he added that once a stigmatized is financially handicapped, perhaps as a result of inheritance or job income, conflicting situations may develop hindering self-attainment 


\subsection{Conclusion}

From the research, the researcher found out that, Self-concept and Socioeconomic Status influenced self-attainment of the stigmatized in Akwa Ibom State.

\subsection{Recommendations}

For counselling to be accorded it full recognition for as a matter of importance and urgency the researcher explores, implores, pleads and recommends that: Counsellors should embark on community counselling periodically in order to prevent self -Concept from being a barrier to one's self-attainment.

1. Churches should introduce psychological group counselling by professional Counsellors to the members on how to overcome Socioeconomic Status hindrances to self-attainment.

Table 1:

\begin{tabular}{|l|l|c|l|l|l|l|l|}
\hline Variables & $\begin{array}{l}\text { Attitude towards } \\
\text { Children's matters }\end{array}$ & $\mathrm{N}$ & Mean & $\mathrm{SD}$ & $\mathrm{t}$-cal & t-crit & Decision at .05 alpha \\
\hline Marital & Negative $\quad 596$ & 74.79 & 8.43 & 3.43 & 1.96 & $\mathrm{~S}$ \\
& & & & & \\
Stability & Positive $\quad 804$ & 76.21 & 6.60 & & \\
\hline
\end{tabular}

The result in table 1 reveals that the calculated t- value of 3.43 is greater than the critical t- value of 1.96 at .05 alpha level of significance with 1092 degree of freedom. This means that self-attainment of the stigmatized is influenced by their self-concept. Hypotheses 2: Socioeconomic status of the stigmatized in Akwa Ibom State does not significantly influence their self-attainment.

Table 2:

\begin{tabular}{|l|l|l|l|l|l|l|l|}
\hline Variable & $\begin{array}{l}\text { Attitude towards } \\
\text { Finance management }\end{array}$ & $\mathrm{N}$ & Mean & $\mathrm{SD}$ & $\mathrm{t}$-cal & $\mathrm{t}$-crit & Decision at .05 alpha \\
\hline Marital & Negative & 624 & 74.16 & 8.50 & & & \\
& & & & 6.37 & 1.96 & $\mathrm{~S}$ \\
& & & & & & \\
Stability $\quad$ Positive & 776 & 76.21 & 6.29 & & & \\
\hline S= Significant at df $=1118$
\end{tabular}

The result in table 2 reveals that the calculated t-value of 6.37 is greater than the critical t- value of 1.98 at .05 alpha level of significance with 1118 degree of freedom. This means that the self-attainment of the stigmatized is influenced by their socioeconomic status.

\section{References}

Carringan, J. (2010). Family Apostolate in Igboland. Rome: Citta Noura Della.

Coff, U. (2011). Understanding Labeling Effect in the Areas of Mental Disorders: An Assessment of the Effects of Expectations of Rejections. American Sociological Review. 52, 96-112.

Effiong, M. (2006).Marriage and Family Happiness. Uyo: Ineme Publishers.

Gelso, N., Williams, H.\&Fretz, N.(2014). The Agony of Childlessness. Makurdi: Onaiva Printing and Publishing Company Limited.

Goffman, I. (2010). Human Development. San Francisco: W.H. Freeman and Company.

Hills, R. (2014). Introduction to Psychology of Learning. Logos: Kufo Printing Press. Holy Bible G.V.

Leigh, D. (2009). Education and Mental Health Stigma: The Effect of Attribution, Biased Assimilation, and Attitude Polarization. Journal of Social and Clinical Psychology. 27, 447-470.

Okokon, N. (2011). Readiness for Parenthood. Onitsha: All Corner Press

Olayinka, H. (2013). Marriage and Family Counselling. Jos: Fab Corners Publishers.

Oliner,C.\&Oliner, D. (1998). Social Psychology of the Stigma of Mental Illness: Public and Self-Stigma Models: U.S.A: The Guilford Press.

Ormrod, J. (2006). What is the Impact of Self-Stigma? Loss of Self-respect and the "Why Try" Effect. Journal of Mental Health,25 (1), 10- 15.

Park,S. \& Water, S. (2009). Empirical Studies of Self-Stigma Reduction Strategies: A critical review of literature Psychiatric Services, 63 (10), 974- 981.

Udoh, M. (2014). For Women in Marriage. Eket: Prince Press

Whiston, N.\& Rahard, N.(2008). The Impact of Stigma on Economic Distress and Recovery from Psychosis: The Mediatory Role of Internalizes Shame and Self-esteem. Psychiatry Research. 255, 94-100. 